\title{
Cinacalcet for Hyperparathyroidism in Pregnancy and Puerperium
}

\author{
Carmen Horjus $^{1}$, Inge Groot ${ }^{2}$, Darryl Telting ${ }^{3}$, Petra van Setten ${ }^{4}$, Adriaan van Sorge ${ }^{5}$, Christopher S. Kovacs ${ }^{6}$, \\ Ad Hermus ${ }^{7}$ and Hans de Boer ${ }^{1}$ \\ Departments of ${ }^{1}$ Internal Medicine, ${ }^{2}$ Gynecology and Obstetrics, ${ }^{3}$ Clinical Chemistry, ${ }^{4}$ Pediatrics and \\ ${ }^{5}$ Clinical Pharmacy, Rijnstate Hospital, Arnhem, The Netherlands, ${ }^{6}$ Faculty of Medicine-Endocrinology, \\ Health Sciences Centre, Memorial University of Newfoundland, St John's, Canada and \\ ${ }^{7}$ Department of Endocrinology, University Medical Center St Radboud, Nijmegen, The Netherlands
}

\begin{abstract}
The efficacy and safety of various modes of medical treatment for primary hyperparathyroidism (PHPT) in pregnancy is largely unknown. This report describes two cases of PHPT in pregnancy that were temporarily treated with the calcimimetic cinacalcet. The first case was diagnosed in the $31^{\text {st }}$ week of pregnancy. The patient was asymptomatic and had an albumin-corrected total calcium level (Ca $\mathrm{a}_{\text {corr }}$ ) of $3.24 \mathrm{mmol} / \mathrm{l}$. As serum calcium was only mildly elevated it was decided to postpone surgery to the postpartum period. Cinacalcet was started immediately after delivery to prevent a postpartum surge in serum calcium. The second patient presented with hypertension and symptomatic hypercalcemia (Ca $\left.\mathbf{C}_{\text {corr }} 3.96 \mathrm{mmol} / \mathrm{l}\right)$ in the $32^{\text {nd }}$ week of pregnancy. Surgery was postponed because of suspected pheochromocytoma. Treatment with a combination of cinacalcet and calcitonin reduced serum $\mathrm{Ca}_{\text {corr }}$ to $\mathbf{3 . 0}$ mmol/l. This report describes the monitoring of mother and child, and explores the pros and cons of the use of calcimimetics during pregnancy and puerperium.
\end{abstract}

\section{KEY WORDS}

hyperparathyroidism, pregnancy, cinacalcet

Reprint address:

H. de Boer, M.D., Ph.D.

Department of Internal Medicine

Ziekenhuis Rijnstate

Wagnerlaan

556800 TA Arnhem, The Netherlands

e-mail: hdeboer@alysis.nl

\section{INTRODUCTION}

The prevalence of primary hyperparathyroidism (PHPT) in women of childbearing age is about 5 per $10,000^{1-3}$. A diagnosis of PHPT is notoriously difficult during pregnancy because it rarely presents with classical symptoms. Most often the symptoms are non-specific and easily mistaken for common pregnancy-related symptoms. In addition, the pregnancy-induced fall in serum albumin reduces the total serum calcium and tends to mask hypercalcemia unless ionized calcium is measured. These are probably the main reasons why PHPT is rarely diagnosed during pregnancy. Since the first case was reported in 1932 , only about 200 cases have been published in the medical literature ${ }^{4}$.

PHPT is typically a disease of middle-aged and elderly women. It usually runs a relatively benign clinical course and rarely needs immediate, lifesaving interventions. In contrast, during pregnancy PHPT may have serious clinical implications for mother and child ${ }^{5-8}$. It may lead to hyperemesis gravidarum, pre-eclampsia, nephrolithiasis, recurrent urinary tract infections, pancreatitis, hypercalcemic crisis, intrauterine growth retardation, miscarriage, stillbirth, preterm labor, neonatal tetany and neonatal death ${ }^{4-8}$. Pregnancy may also develop uneventfully but even in cases of mild PHPT severe fetal/neonatal complications have been reported. At present there are no evidencebased parameters that reliably predict the outcome of PHPT in pregnancy, but most experts suggest that severe complications are less likely if the total serum calcium remains below $3.0 \mathrm{mmol} / \mathrm{l}$.

Because the outcome cannot be accurately predicted, it is not surprising that the optimal management of PHPT during pregnancy is unresolved. Most authors advocate parathyroidectomy 
(PTx) during pregnancy as the treatment of choice in the second trimester?. The safety of surgery in the first and third trimesters is debated because of the associated risks for the fetus ${ }^{9}$. Experience with medical treatment for PHPT in pregnancy is very limited and poorly documented. In less than $20 \%$ of reported cases were adequate details provided about the medical interventions and outcome. So far, only intravenous hydration with or without forced diuresis, and intravenous or subcutaneous calcitonin have emerged as safe treatments ${ }^{10}$. Both will lower serum calcium only temporarily, and additional treatment of the underlying cause will always be needed to prevent recurrent hypercalcemia. $\mathrm{MgSO}_{4}$ may be used to increase urinary calcium excretion ". Oral or intravenous phosphate is not recommended because it may cause extensive intraand extravascular calcium phosphate deposits which may lead to severe organ failure ${ }^{12}$. Bisphosphonates cross the placenta and have been shown in some animal models to interfere with normal endochondral bone development. They should only be used in emergencies as a short-term intervention to stabilize severe hypercalcemia prior to surgery ${ }^{13,14}$.

Calcimimetics are effective in reducing serum calcium in PHPT; however, their use in pregnancy has not yet been reported ${ }^{15,16}$. To our knowledge, this is the first report describing the effects of the calcimimetic cinacalcet during pregnancy and puerperium.

\section{PATIENT 1}

A 35 year-old pregnant women, G2P1, was referred to the Department of Endocrinology because of recently discovered mild primary hypothyroidism: free T4 $11 \mathrm{pmol} / \mathrm{l}$ (normal range [NR]: 11-25 pmol/l), TSH $4.87 \mathrm{mU} / \mathrm{l}$ (NR: 0.3-4.0 mU/l), anti-TPO antibodies negative. Thyroid replacement therapy was started and euthyroidism was soon established with thyroxin at a dose of $50 \mu \mathrm{g}$ once per day. She had used multivitamins on a daily basis since gastric banding for morbid obesity 5 years earlier. Additional blood tests were performed in the $31^{\text {st }}$ week of pregnancy to rule out hypo- or hypervitaminosis. The results were compatible with PHPT: serum total calcium 3.06 $\mathrm{mmol} / \mathrm{l}$, albumin $29.5 \mathrm{~g} / 1$, albumin-corrected total calcium level $\left(\mathrm{Ca}_{\text {corr }}\right) 3.32 \mathrm{mmol} / \mathrm{l}$, ionized calcium $\left(\mathrm{Ca}^{2+}\right) 1.60 \mathrm{mmol} / \mathrm{l}$, phosphate $0.71 \mathrm{mmol} / \mathrm{l}$, parathyroid hormone (PTH) $6.1 \mathrm{pmol} / \mathrm{l}$ (NR in nonpregnant women: 1.6-6.9 pmol/l), 25-hydroxyvitamin D $41 \mathrm{nmol} / \mathrm{l}$ (NR: 50-100 nmol/l), 1,25dihydroxy-vitamin D $269 \mathrm{pmol} / \mathrm{l}$ (NR: 48-161 $\mathrm{pmol} / \mathrm{l}$ ), and urinary calcium excretion $25.1 \mathrm{mmol} /$ $24 \mathrm{~h}$. Five years previously, serum total calcium and phosphate levels had been within the normal range $\left(\mathrm{Ca}^{2+} 2.43 \mathrm{mmol} / \mathrm{l}\right.$, phosphate $\left.0.89 \mathrm{mmol} / \mathrm{l}\right)$. Ultrasonography of the neck revealed a right inferior parathyroid adenoma of $0.9 \times 1.6 \mathrm{~cm}$. Abdominal ultrasonography of the kidneys was normal.

The patient was hospitalized in the $32^{\text {nd }}$ week of pregnancy to monitor calcium and phosphate metabolism. She was advised to maintain a fluid intake of 4 liters per day to ensure high urinary calcium excretion. Serum $\mathrm{Ca}^{2+}$ levels and urinary calcium excretion remained stable during the first week (Fig. 1). Fetal ultrasound showed normal fetal development without growth retardation. In a multidisciplinary discussion it was concluded that PTx was not the option of choice in this phase of pregnancy because of the associated risk of preterm labor. It was decided to perform a preterm delivery at 36 weeks, either by induction of labor or by Cesarean section. At 36 weeks labor induction with oxytocin i.v. and dinoprostone gel treatment was not successful. Therefore, a Cesarean section was carried out as planned. A healthy son was delivered, body weight $3,390 \mathrm{~g}\left(>90^{\mathrm{th}}\right.$ percentile), height $52 \mathrm{~cm}$, head circumference $35.5 \mathrm{~cm}$, Apgar score 8-9, umbilical cord serum $\mathrm{Ca}^{2+} 1.77 \mathrm{mmol} / \mathrm{l}$. i.e. $0.37 \mathrm{mmol} / \mathrm{l}$ higher than that of the mother (Fig. 1). Macroscopic and microscopic examination of the placenta did not reveal any abnormalities.

At the time of delivery, the mother's serum $\mathrm{Ca}^{2+}$ of $1.40 \mathrm{mmol} / \mathrm{l}$ was rather low. This was attributed to extensive fluid infusion which had been necessary to maintain blood pressure during the Cesarean section. To prevent a rapid surge of serum calcium in the postpartum period, cinacalcet $30 \mathrm{mg}$ twice per day was started immediately after delivery, in combination with infusion of $0.9 \% \mathrm{NaCl}$ at a rate of $4 \mathrm{l} / 24 \mathrm{~h}$. During the subsequent days $\mathrm{Ca}^{2+}$ gradually decreased, and 7 days after the Cesarean 

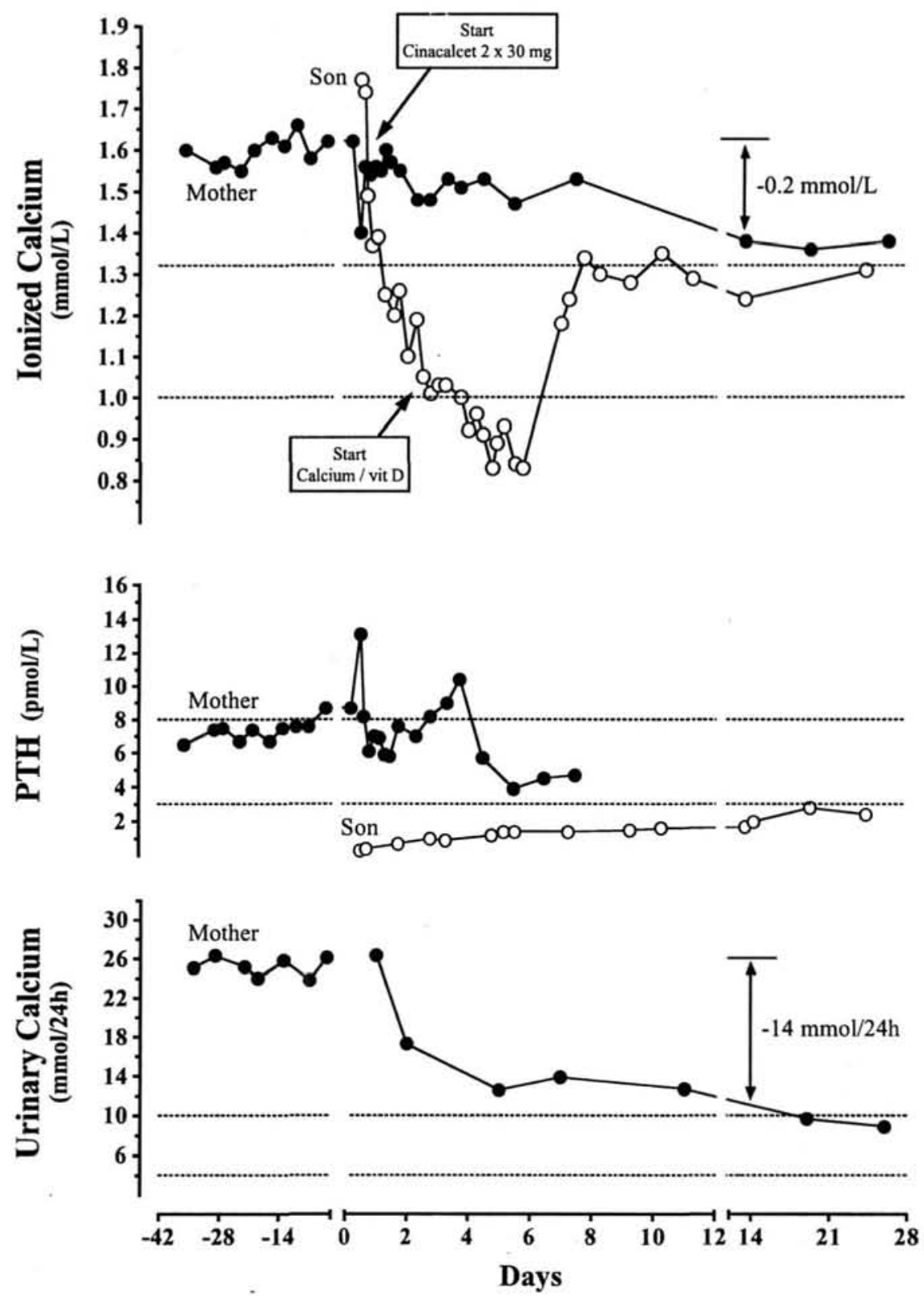

Fig. 1: Patient 1. Serum ionized calcium in mother and child during pregnancy and puerperium $(0=$ delivery $)$.

section the mother was discharged. Serum $\mathrm{Ca}^{2+}$ stabilized between 1.30 and $1.40 \mathrm{mmol} / \mathrm{l}$ on cinacalcet. Six weeks after delivery a right inferior parathyroid adenoma of $2 \mathrm{~cm}$ was removed, and this completely normalized serum calcium.

\section{The neonate}

Immediately after delivery, the infant was transferred to the neonatal intensive care unit. Labora- tory results from cord blood samples are summarized in Table 1. The son's serum $\mathrm{Ca}^{2+}$ level was $0.37 \mathrm{mmol} / \mathrm{l}$ higher than that of his mother. Serum phosphate was markedly higher in the neonate, whereas serum PTH and PTH-related protein (PTHrp) were suppressed. Serum calcitonin was nearly 20 -fold higher than in the mother. The neonate's $1,25-(\mathrm{OH})_{2}$-vitamin D was half the level observed in the mother, whereas $25-\mathrm{OH}$-vitamin D levels were comparable. Vitamin D binding protein 
TABLE 1

Laboratory results in mother and infant (Patient 1), just after Cesarean section

\begin{tabular}{|c|c|c|c|}
\hline & Mother & Infant & Normal range \\
\hline $\mathrm{Ca}_{\text {corr }}(\mathrm{mmol} / \mathrm{l})$ & 3.06 & 3.45 & $2.10-2.55$ \\
\hline $\mathrm{Ca}^{2+}(\mathrm{mmol} / \mathrm{l})$ & 1.40 & 1.77 & $1.10-1.30$ \\
\hline Albumin $(\mathrm{g} / \mathrm{l})$ & 20.8 & 23.8 & $35-50$ \\
\hline pH & 7.46 & 7.38 & $7.35-7.45$ \\
\hline Phosphate $(\mathrm{mmol} / \mathrm{l})$ & 0.74 & 1.83 & $0.87-1.45$ \\
\hline PTH $(\mathrm{pmol} / \mathrm{l})$ & 13.1 & 0.3 & $1.6-6.9$ \\
\hline PTHrp (pmol/l) & $<0.3$ & $<0.3$ & $0-0.6$ \\
\hline Calcitonin (pmol/l) & 0.7 & 13.6 & $0-4.7$ \\
\hline 25-OH-Vitamin $\mathrm{D}_{3}(\mathrm{nmol} / \mathrm{l})$ & 48 & 40 & $50-100$ \\
\hline $1,25-(\mathrm{OH})_{2}$-Vitamin $\mathrm{D}_{3}(\mathrm{pmol} / \mathrm{l})$ & 362 & 187 & $48-161$ \\
\hline Vitamin D binding protein $(\mu \mathrm{g} / \mathrm{ml})$ & 431 & 257 & $217-449$ \\
\hline
\end{tabular}

For abbreviations see text. Normal ranges refer to normal values in non-pregnant adults.

was in the low normal range in the neonate and in the high normal range in the mother. Ionized calcium decreased rapidly and two days after delivery a level of $1.10 \mathrm{mmol} / \mathrm{l}$ was reached. Infusion of calcium and oral ingestion of $1 \alpha-$ calcidiol was started, but this did not prevent a further decline of serum $\mathrm{Ca}^{2+}$ to $0.80 \mathrm{mmol} / \mathrm{l}$. Neonatal tetany did not occur. Six days after the start of treatment a consistent rise in serum calcium was achieved, ending with a $\mathrm{Ca}^{2+}$ level around 1.30 $\mathrm{mmol} / \mathrm{l}$. The child was discharged in good health on day 15. After 2 months calcium and vitamin D supplementation was stopped permanently.

\section{PATIENT 2}

A 40 year-old female, G2P0, was hospitalized in the $32^{\text {nd }}$ week of pregnancy because of progressive hypertension $(180 / 110 \mathrm{~mm} \mathrm{Hg})$ not responding to methyldopa. There was no evidence of preeclampsia. Polyuria (10-12 liters daily) and polydipsia was noted and this prompted further evaluation. Laboratory results were compatible with a diagnosis of severe PIIPT: total calcium 3.57 $\mathrm{mmol} / \mathrm{l}$, albumin $24.6 \mathrm{~g} / \mathrm{l}, \mathrm{Ca}_{\text {corr }} 3.967 \mathrm{mmol} / \mathrm{l}$, $\mathrm{Ca}^{2+} 1.98 \mathrm{mmol} / \mathrm{l}$, phosphate $0.65 \mathrm{mmol} / \mathrm{l}$, PTI $16.1 \mathrm{pmol} / \mathrm{l}$, urinary calcium excretion $32.7 \mathrm{mmol} /$ 24 h. Plasma glucose, creatinine, and sodium were within the normal range. Ultrasonography of the neck did not reveal a parathyroid adenoma. Because of the combination of hypertension and PHPT a MEN 2A syndrome could not be ruled out with certainty and thus parathyroid surgery was postponed pending further analysis. Intravenous hydration with $0.9 \% \mathrm{NaCl}, 6$ liter $/ 24 \mathrm{~h}$, did not reduce serum $\mathrm{Ca}^{2+}$. Calcitonin alone was considered ineffective for the long-term $\mathrm{Ca}^{2+}$ control needed in this case, and so we chose to start treatment with cinacalcet $30 \mathrm{mg}$ twice daily. The dose was rapidly increased to $240 \mathrm{mg} / \mathrm{day}$, within one week. This resulted in a temporary reduction of maternal serum $\mathrm{Ca}^{2+}$ after three days, but after one week of treatment serum $\mathrm{Ca}^{2+}$ had increased to its original level. Calcitonin was added, first at a dose of 200 $\mu \mathrm{g}$ subcutaneously, and then $100 \mu \mathrm{g}$ subcutaneously every other day. The combined regimen reduced 
serum $\mathrm{Ca}^{2+}$ to a stable level of around $1.50 \mathrm{mmol} / 1$ (Fig. 2). After confirmation that urinary catecholamine excretion was normal, surgery was planned for the $34^{\text {th }}$ week. Cesarean section was performed first, directly followed by a right parathyroid adenomectomy in the same session. A cord blood sample taken immediately after delivery showed elevated neonatal serum $\mathrm{Ca}^{2+}$ as compared to the mother, indicating that the physiological $\mathrm{Ca}^{2+}$ gradient between mother and child was maintained during the use of cinacalcet (Table 2). Vitamin D and calcium supplementation was started on the second day when serum $\mathrm{Ca}^{2+}$ had decreased to 1.05 $\mathrm{mmol} / \mathrm{l}$. Neonatal tetany did not occur. Vitamin D and calcium supplementation was stopped after 11 days.

\section{DISCUSSION}

This paper describes the use of cinacalcet in two cases of PHPT in pregnancy. The first case is an example of asymptomatic, mild hyperparathyroidism diagnosed in the third trimester of pregnancy. Decisions about when and how to intervene are

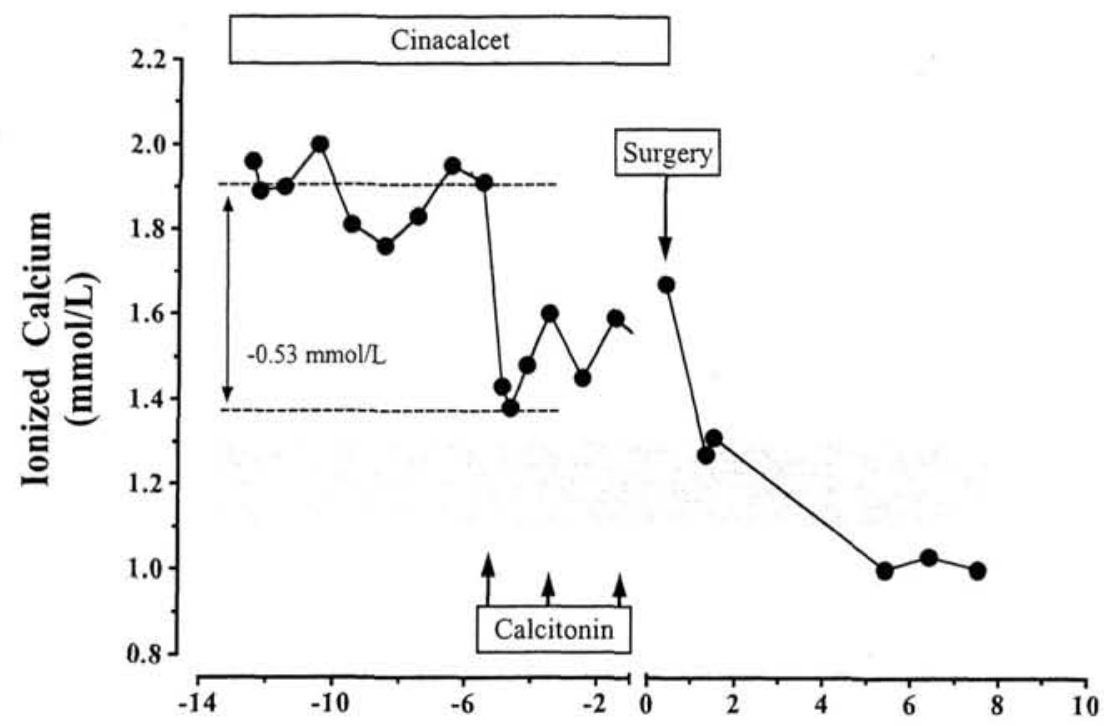

Fig. 2: Patient 2. Effect of cinacalcet monotherapy, combination treatment with cinacalcet and calcitonin, and subsequent surgery on maternal ionized calcium levels in the third trimester of pregnancy.

TABLE 2

Effects of cinacalcet and calcitonin treatment on neonatal calcium homeostasis (Patient 2)

\begin{tabular}{lcc}
\hline & Mother & Child \\
\hline Total calcium $(\mathrm{mmol} / \mathrm{l})$ & 3.01 & 3.28 \\
$\mathrm{Ca}^{2+}(\mathrm{mmol} / \mathrm{l})$ & 1.67 & 1.85 \\
Albumin $(\mathrm{g} / \mathrm{l})$ & 22.9 & 27.2 \\
PTH $(\mathrm{pmol} / \mathrm{l})$ & 32.5 & $<1$ \\
Phosphate $(\mathrm{mmol} / \mathrm{l})$ & 1.38 & 2.52 \\
\hline
\end{tabular}

Laboratory results of samples obtained immediately after delivery.

Normal ranges are shown in Table 1. 
difficult in cases like this because systematically analyzed clinical data are not available to guide our judgment. At present, we do not know exactly what threshold level of serum calcium is associated with increased risks of serious complications. As demonstrated by this patient, pregnancy may continue uneventfully in cases of mild PIPT; however, this case also illustrates that even mild maternal hypercalcemia can cause neonatal hypocalcemia and hypoparathyroidism.

Withholding calcium lowering treatment during pregnancy may put the mother and fetus at risk for more severe complications ${ }^{17}$. The use of cinacalcet during pregnancy was discussed at length but eventually rejected because of lack of safety data in humans. Conservative management with watchful waiting until full term was considered too dangerous because any event associated with a decline in renal function might compromise calcium excretion and could thus precipitate a hypercalcemic crisis. It was decided to provide adequate hydration and plan a preterm delivery at 36 weeks to avoid the physiological decline in maternal glomerular filtration rate (GFR) that occurs in the late phase of pregnancy ${ }^{18}$. We also started cinacalcet immediately after delivery to prevent a rise in serum calcium that might occur as a result of the loss of calcium shunting to the fetus, the rapid decline in GFR that follows delivery, and the onset of accelerated bone resorption with early lactation. As shown in Figure 1, cinacalcet gradually lowered serum $\mathrm{Ca}^{2+}$ to $1.36 \mathrm{mmol} / \mathrm{l}$ in 2 weeks, and parathyroid surgery was safely postponed until the patient had recovered from the Cesarean section.

The second case is, to our knowledge, the first to demonstrate that the use of cinacalcet for PHPT in pregnancy does not compromise fetal blood calcium or apparent placental calcium transport. At birth the neonatal $\mathrm{Ca}^{2+}$ level was $0.18 \mathrm{mmol} / \mathrm{l}$ higher than in the mother (Table 2). This case also illustrates that cinacalcet monotherapy is not useful for the acute control of serum calcium in severe PHPT (Fig. 2). To some extent this was expected since at least 2 weeks of treatment of non-pregnant patients with PIIPT are required to reach the nadir calcium levels for a given dose ${ }^{15}$. We hoped to induce an earlier response by rapidly increasing the dose up to its maximum. Unfortunately, only a temporary decline was observed, and after one week of treatment serum calcium was again at its peak level. In contrast, the combination of cinacalcet and calcitonin proved highly effective in reducing serum $\mathrm{Ca}^{2+}$ to our target level of $1.50 \mathrm{mmol} / \mathrm{l}$. We did not wish to normalize serum calcium because too large a decline in serum calcium might trigger premature labor or compromise fetal calcium metabolism. Serum calcium was monitored every 6 hours, and this permitted careful titration of calcitonin. After an initial dose of $200 \mu \mathrm{g}$ of calcitonin, a dose of $100 \mu \mathrm{g}$ every other day in combination with cinacalcet was sufficient to maintain serum calcium at the desired level. Monotherapy with calcitonin every other day would not have achieved this consistent lowering in serum calcium given the rapid tachyphylaxis that occurs in response to calcitonin. We hypothesize that the combination treatment prevents the PTH surges that are likely to occur in response to the calcium lowering effects of calcitonin monotherapy.

Before considering cinacalcet treatment we extensively discussed the pros and cons because its use in human pregnancy had not been previously reported. Cinacalcet is a calcimimetic that activates the calcium sensing receptor (CaSR) present on parathyroid cells, C-cells of the thyroid, and renal distal tubular cells. Activation of the CaSR reduces PTH secretion and increases calcitonin release, whereas activation of the renal tubular cell CaSR reduces renal calcium resorption independently of changes in $\mathrm{PTH}^{19}$. Cinacalcet has been used successfully to treat PHPT in non-pregnant women $^{15.16}$. The recommended starting dose is $30 \mathrm{mg}$ twice a day, and it may be increased to up to 180 $360 \mathrm{mg} /$ day. It takes about 2 weeks before steady state is reached on a given dose. Safety and efficacy have not been established in patients below the age of 18 years. Animal studies in pregnant rats and rabbits have shown that cinacalcet crosses the placenta; however, embryonal or fetal toxicity or harmful effects with respect to pregnancy or parturition have not been observed ${ }^{20}$. Based on these data, cinacalcet has been classificd as a category $\mathrm{C}$ drug. Considering the demonstrated efficacy of cinacalcet in non-pregnant women, there is little doubt that cinacalcet will also lower serum 
calcium in pregnant women. It should thus reduce the feto-maternal complications of hyperparathyroidism that are due to the hypercalcemia. However, there are two main concerns for its use in pregnancy. First, effects on fetal calcium levels have not been studied previously; secondly, direct frequent monitoring of fetal calcium levels is not feasible. CaSRs are present in the placenta, and thus cinacalcet might alter placental function to cause fetal hypocalcemia, for example by suppressing fetal PTH secretion, placental PTHrp production, or the production of other factors contributing to active placental calcium transport ${ }^{17}$. On the other hand, several lines of evidence suggest that the use of cinacalcet is likely to be safe, as long as the mother is not made hypocalcemic. In normal pregnancy, fetal ionized calcium is about $0.3 \mathrm{mmol} / 1$ higher than in the mother, due to active transport of calcium across the placenta ${ }^{17}$. These high fetal calcium levels suppress fetal parathyroid activity, and fetal PTH levels are normally low or even undetectable. In cases of maternal PHPT fetal calcium levels are even higher and this will completely suppress fetal PTH secretion. Thus, it is very unlikely that cinacalcet would adversely affect fetal parathyroid activity during PHPT in pregnancy, simply because fetal PTH production would already be maximally suppressed in response to the maternal hypercalcemia.

Potential adverse effects of cinacalcet on placental active calcium transport are more difficult to predict. To some extent, the safety of CaSR modulation in humans can be deduced from an experiment of nature, i.e. a gain-of-function mutation of the CaSR. In affected children the CaSR is overly sensitive to the effects of calcium to such a degree that even subnormal calcium levels can suppress PTH secretion and renal tubular calcium resorption. This results in a clinical syndrome known as autosomal dominant hypocalcemia (ADH), which is characterized by hypocalcemia and hypercalciuria ${ }^{21-30}$. Most affected individuals are detected during childhood or later in life because of muscle spasms or seizures. A large group is asymptomatic and only detected during family survey, and only a very small number present with tetany in the neonatal period. Table 3 summarizes all reported cases of ADH presenting with neonatal tetany or with known calcium levels in the neonatal period. All cases had an uneventful pregnancy and delivery, even those from affected mothers. None presented with hypocalcemic seizures on the first day of life. The earliest symptomatic infant had seizures at 3 days of age ${ }^{26}$. This relatively late onset of symptomatic hypocalcemia suggests that calcium levels are likely to have been normal at birth and imply that fetal calcium homeostasis is not adversely affected by an increase in CaSR sensitivity. Even in affected mothers with serum total calcium levels between 1.63 and 1.75 $\mathrm{mmol} / \mathrm{l}$ the placental calcium pump must have been functioning quite well as neonatal tetany occurred as late as 6-7 days after birth. Apparently, the placental CaSR is not pivotal in the regulation of placental calcium transport.

Adverse effects of cinacalcet on neonatal calcium homeostasis are also unlikely. As cinacalcet has a half life of about 30 hours its effect will be negligible after 3 days. A clinically significant lengthening of the neonatal hypocalcemic period is thus unlikely. The use of cinacalcet could conceivably reduce the neonatal hypocalcemic period, because lowering the maternal serum calcium toward normal may lead to an increase in fetal PTH from the typically undetectable levels associated with maternal hypercalcemia. By reducing the suppressive effects of maternal hypercalcemia on fetal parathyroid development, this may speed up the recovery of normal parathyroid function in the neonatal period. The events in the neonate of Patient 2 support this line of thought.

In conclusion, this report indicates that the combination of cinacalcet and calcitonin may be an effective approach to treat selected cases of PHPT in the third trimester of pregnancy before surgery can be safely performed. Clearly, additional studies are needed to determine this treatment's relative benefits and safety issues with respect to the mother and fetus/neonate. Due to cinacalcet's delayed onset of action, monotherapy is not useful for the rapid correction of severe PHPT in pregnancy unless combined with calcitonin. However, cinacalcet monotherapy may prove useful for mild PHPT in the third trimester of pregnancy to postpone surgery and avoid preterm labor or to prevent severe neonatal hypoparathyroidism. 
TABLE 3

Timing of unset of symptoms and biochemical characteristics at the onset of symptoms in newborns with a gain-of-function mutation of the calcium sensing receptor (CaSR) of affected and unaffected mothers

\begin{tabular}{cccccc}
\hline Genetics & Pregnancy & Delivery & First symptoms & Calcium M/N* & Reference \\
\hline A & uneventful & $38 \mathrm{wk}$ & 6 days & $1.58 / 1.23$ & 21 \\
A & NR & NR & 7 days & $1.58 / 1.48$ & 21 \\
A & NR & NR & 5 years & $1.63 / 1.78$ & 22 \\
A & NR & NR & 'asymptomatic at birth' & $1.63 / 1.78$ & 22 \\
A & NR & NR & 'asymptomatic at birth' & $1.63 / 1.85$ & 22 \\
A & uneventful & term & 7 months & $1.50 / 1.65$ & 23 \\
A & uneventful & 37 wk & 7 days & $1.75 / 1.30$ & 24 \\
A & NR & NR & 3 years & $1.75 / 1.75$ & 24 \\
B & NR & NR & 'shortly after birth' & NL/1.76 & 25 \\
B & uneventful & term & 3 days & NL/1.45 & 26 \\
C & uneventful & term & 24 days & NL/1.10 & 27 \\
C & uneventful & $38 \mathrm{wk}$ & 5 days & NL/1.30 & 27 \\
C & uneventful & $37 \mathrm{wk}$ & 21 days & NL/1.54 & 28 \\
C & twin & 34 wk & 7 days & NL/1.25 & 29 \\
C & twin & 34 wk & 8 days & NL/0.99 & 29 \\
C & uneventful & $37 \mathrm{wk}$ & 14 days & NL/1.70 & 30 \\
\hline
\end{tabular}

Genetics: $\mathrm{A}=$ mother and child affected; $\mathrm{B}=$ mother not affected, only father and child affected; $\mathrm{C}=$ child affected due to de novo mutation.

$\mathrm{NR}=$ not reported; $\mathrm{NL}=$ normal.

* Serum total calcium in mother $(M)$ and neonate $(\mathrm{N})$ at the time of diagnosis in $\mathrm{mmol} / \mathrm{l}$.

The authors declare no conflict of interest.

\section{REFERENCES}

1. Palmer M, Jakobsson S, Åkerström G, Ljunghall S. Prevalence of hypercalcemia in a health survey: a 14year follow-up study of serum calcium values. Eur $\mathrm{J}$ Clin Invest 1988; 18: 39-46.

2. Jorde R, Bönaa KH, Sundsfjord J. Primary hyperparathyroidism detected in a health screening. The Tromsö study. J Clin Epidemiol 2000; 53: 1164-1169.

3. Christensson $T$, Hellström $K$, Wengle $B$, Alveryd A, Wikland B. Prevalence of hypercalcemia in a health screening in Stockholm. Acta Med Scand 1976; 200: 131-137.
4. Bevere L, Sorrentino B. Contributo allo studio dell' osteite fibrocystica generalizzata. Riforma Med 1932; 48: 313-318.

5. Ludwig GD. Hyperparathyroidism in relation to pregnancy. N Engl J Med 1962; 267: 637-642.

6. Shangold MM, Dor N, Welt SI, Fleischman AR, Crenshaw MC Jr. Hyperparathyroidism and pregnancy: a review. Obstet Gynecol Surv 1982; 37: 217-228.

7. Schnatz PF, Curry SL. Primary hyperparathyroidism in pregnancy: evidence-based management. Obstet Gynecol Surv 2002; 57: 365-376.

8. Schnatz PF, Thaxton S. Parathyroidectomy in the third trimester of pregnancy. Obstet Gynecol Surv 2005; 10: 672-682.

9. Goodman S. Anesthesia for nonobstetric surgery in the pregnant patient. Semin Perinatol 2002; 26: 136-145. 
10. Sjöberg HE, Hjern B. Acute treatment with calcitonin in primary hyperparathyroidism and severe hypercalcemia of other origin. Acta Chir Scand 1975; 141 : 90-95.

11. Cruikshank DP, Pitkin RM. Donnelly E, Reynolds WA. Urinary magnesium, calcium, and phosphate excretion during magnesium sulfate infusion. Obstet Gynecol 1981; 58: 430-434.

12. Vernava AM, O'Neal LW, Palermo V. Lethal hyperparathyroid crisis: hazards of phosphate administration. Surgery 1987; 102: 941-948.

13. Phitayakorn R, McHenry CR. Hyperparathyroid crisis: use of bisphosphonates as a bridge to parathyroidectomy. J Am Coll Surg 2008; 206: 1106-1 105.

14. Culbert EC, Schfirin BS. Malignant hypercalcemia in pregnancy. Effects of pamidronate on uterine contractions. Am Coll Obstet Gynecol 2006; 108: 789-791.

15. Shoback DM, Bilezikian JP, Turner SA, McCary LC, Guo MD, Peacock M. The calcimimetic cinacalcet normalizes serum calcium in subjects with primary hyperparathyroidism. J Clin Endocrinol Metab 2003; 88: 5644.

16. Peacock M, Bilezikian JP, Klassen PS, Guo MD, Turner SA, Shoback D. Cinacalcet hydrochoride maintains long-term normocalcemia in patients with primary hyperparathyroidism. J Clin Endocrinol Metab 2005; 90: 135-141.

17. Kovacs CS, Fuleihan GEH. Calcium and bone metabolism during pregnancy and lactation. Endocrinol Metab Clin North Am 2006; 35: 21-51.

18. Lindheimer MD, Katz AI. Renal physiology and disease in pregnancy. In: Seldin DW, Giebisch G, eds. The Kidney, Physiology and Pathophysiology. New York: Raven Press, 1992; 3371-3431.

19. Nagano N. Pharmacological and clinical properties of calcimimetics: calcium receptor activators that afford an innovative approach to controlling hyperparathyroidism. Pharmacol Ther 2006; 109: 339-365.

20. Amgen. Sensipar drug leaflet, 2008.

21. Watanabe $T$, Bai $M$, Lane $C R$, Matsumoto $S$, Minamitani K, Minagawa M, Niimi H, Brown EM, Yasuda T. Familial hypoparathyroidism: identification of a novel gain of function mutation in transmembrane domain 5 of the calcium-sensing receptor. J Clin Endocrinol Metab 1998; 83: 2497-2502.

22. Lienhardt A, Garabedian M, Bai M, Sinding C, Zhang Z, Lagarde JP, Boulesteix J, Rigaud M, Brown EM, Kottler ML. A large homozygous or heterozygous in- frame deletion within the calcium-sensing receptor's carboxyterminal cytoplasmic tail that causes autosomal dominant hypocalcemia. J Clin Endocrinol Metab 2000; 85: 1695-1702.

23. Hirai $H$, Nakajima $S$, Miyauchi A, Nishimura $K$, Shimizu N, Shima M, Michigami T, Ozono K, Okada $S$. A novel activating mutation (C129S) in the calciumsensing receptor gene in a Japanese family with autosomal dominant hypocalcemia. J Hum Genet 2001; 46: $41-44$.

24. Chikatsu N, Watanabe S, Takeuchi $Y$, Muraosa $Y$, Sasaki S, Oka Y, Fukumoto S, Fujita T. A family of autosomal dominant hypocalcemia with an activating mutation of calcium-sensing receptor gene. Endocr $\mathrm{J}$ 2003; 50: 91-96.

25. Tan YM, Cardinal J, Franks AH, Mun HC, Lewis N, Harris LB, Prins JB, Conigrave AD. Autosomal dominant hypocalcemia: a novel activating mutation (E604K) in the cysteine-rich domain of the calciumsensing receptor. J Clin Endocrinol Metab 2003; 88: 605-610.

26. Uckun-Kitapci A, Underwood LE, Zhang J, MoatsStaats B. A novel mutation (E767K) in the second extracellular loop of the calcium sensing receptor in a family with autosomal dominant hypocalcemia. Am J Med Genet 2005; 132A: 125-129.

27. Sato K, Hasegawa $Y$, Nakae J, Nanao K, Takahashi I, Tajima T, Shinohara N, Fujieda K. Hydrochlorothiazide effectively reduces urinary calcium excretion in two Japanese patients with gain-of-function mutations of the calcium-sensing receptor gene. J Clin Endocrinol Metab 2002; 87: 3068-3073.

28. Vargas-Poussou R, Huang C, Hulin P, Houillier P, Jeunemaître $X$, Paillard $M$, Planelles $G$, Déchaux $M$, Miller RT, Antignac C. Functional characterization of a calcium-sensing receptor in severe autosomal dominant hypocalcemia with a Bartter-like syndrome. J Am Soc Nephrol 2002; 13: 2259-2266.

29. Hu J, Mora S, Weber G, Zamproni I, Proverbio MC, Spiegel AM. Autosomal dominant hypocalcemia in monozygotic twins caused by a de novo germline mutation near the amino-terminus of the human calcium receptor. J Bone Miner Res 2004; 19: 578-586.

30. Shiohara M, Mori T, Mei B, Brown EM, Watanabe T, Yasuda T. A novel gain-of-function mutation (F821L) in the transmembrane domain of calcium-sensing receptor is a cause of severe sporadic hypoparathyroidism. Eur J Pediatr 2004; 163: 94-98. 
Brought to you by | Memorial Univ.of Newfoundland (Memorial Univ.of Newfoundland)

Authenticated | 172.16.1.226

Download Date | 7/24/12 3:36 PM 